\title{
Muscarinic receptor subtype-specific effects on cigarette smoke-induced inflammation in mice
}

\author{
Loes E.M. Kistemaker ${ }^{1,2}$, I. Sophie T. Bos ${ }^{1,2}$, Machteld N. Hylkema ${ }^{2,3}$, \\ Martijn C. Nawijn ${ }^{2,3}$, Pieter S. Hiemstra ${ }^{4}$, Jürgen Wess ${ }^{5}$, Herman Meurs ${ }^{1,2}$, \\ Huib A.M. Kerstjens ${ }^{2,6}$ and Reinoud Gosens $s^{1,2}$
}

\begin{abstract}
Affiliations: 'Dept of Molecular Pharmacology, University of Groningen, Groningen, ${ }^{2}$ GRIAC Research Institute, University Medical Centre Groningen, University of Groningen, Groningen, ${ }^{3}$ Dept of Pathology and Medical Biology, University Medical Centre Groningen, Groningen, ${ }^{4}$ Dept of Pulmonology, Leiden University Medical Centre, Leiden, ${ }^{6}$ Dept of Respiratory Medicine, University Medical Centre Groningen, Groningen, The Netherlands, ${ }^{5}$ Molecular Signaling Section, Laboratory of Bioorganic Chemistry, National Institute of Diabetes and Digestive and Kidney Diseases, National Institutes of Health, Bethesda, MD, USA.
\end{abstract}

Correspondence: L.E.M. Kistemaker, Dept of Molecular Pharmacology, University of Groningen, A. Deusinglaan 1, 9713 AV Groningen, The Netherlands. E-mail: l.e.m.kistemakerarug.nl

ABSTRACT Cholinergic tone contributes to airflow obstruction in chronic obstructive pulmonary disease. Accordingly, anticholinergics are effective bronchodilators by blocking the muscarinic $\mathrm{M}_{3}$ receptor on airway smooth muscle. Recent evidence indicates that acetylcholine also contributes to airway inflammation. However, which muscarinic receptor subtype(s) regulates this process is unknown.

In this study, the contribution of the $\mathrm{M}_{1}, \mathrm{M}_{2}$ and $\mathrm{M}_{3}$ receptor subtypes to cigarette smoke-induced airway inflammation was investigated by exposing muscarinic receptor subtype deficient mice to cigarette smoke for 4 days.

In wild-type mice, cigarette smoke induced an increase in macrophages, neutrophils and lymphocytes in bronchoalveolar lavage fluid. Neutrophilic inflammation was higher in $\mathrm{M}_{1}{ }^{-/-}$and $\mathrm{M}_{2}^{-/-}$mice compared to wild-type mice, but lower in $\mathrm{M}_{3}{ }^{-/-}$mice. Accordingly, the release of keratinocyte-derived chemokine (KC), monocyte chemotactic protein-1 and interleukin- 6 was higher in $\mathrm{M}_{1}{ }^{-/-}$and $\mathrm{M}_{2}{ }^{-/-}$mice, and reduced in $\mathrm{M}_{3}{ }^{-/-}$ mice. Markers of remodelling were not increased after cigarette smoke exposure. However, $\mathrm{M}_{3}^{-1-}$ mice had reduced expression of transforming growth factor- $\beta 1$ and matrix proteins. Cigarette smoke-induced inflammatory cell recruitment and $\mathrm{KC}$ release were also prevented by the $\mathrm{M}_{3}$-receptor selective antagonist 1,1-dimethyl-4-diphenylacetoxypiperidinium iodide (4-DAMP) in wild-type mice.

Collectively, our data indicate a pro-inflammatory role for the $\mathrm{M}_{3}$ receptor in cigarette smoke-induced neutrophilia and cytokine release, yet an anti-inflammatory role for $\mathrm{M}_{1}$ and $\mathrm{M}_{2}$ receptors.

@ERSpublications

Inhibition of the muscarinic $\mathrm{M}_{3}$ receptor prevents inflammation in response to cigarette smoke exposure in mice http://ow.ly/p7UdG

This article has supplementary material available from www.erj.ersjournals.com

Received: July 192012 | Accepted after revision: Jan 212013 | First published online: Feb 082013

Support statement: We would like to thank the Netherlands Asthma Foundation for financial support (grant 3.2.08.014).

Conflict of interest: Disclosures can be found alongside the online version of this article at www.erj.ersjournals.com

Copyright @ERS 2013 


\section{Introduction}

Chronic obstructive pulmonary disease (COPD) is an inflammatory disease characterised by progressive airflow limitation that is not fully reversible [1]. The most common cause of COPD in the Western world is tobacco smoking. Inflammation plays a central role in the disease, and contributes to the airway fibrosis, mucus hypersecretion and emphysema that is observed in patients with COPD [1]. Macrophages and neutrophils are particularly increased in patients with COPD and this increase is related to an increased production of specific cytokines and chemokines, including interleukin (IL)-8, IL-6, IL-1 $\beta$, IL-17, monocyte chemotactic protein (MCP)-1 and tumour necrosis factor (TNF)- $\alpha$ [2]. Moreover, COPD is associated with an increased production of growth factors, including transforming growth factor (TGF)- $\beta$ and vascular endothelial growth factor (VEGF), which are thought to contribute to the remodelling of the airways [3].

Acetylcholine is the primary parasympathetic neurotransmitter that induces bronchoconstriction in the airways. Parasympathetic activity is increased in patients with COPD, and this appears to be the major reversible component of airway obstruction [4]. Therefore, treatment with anticholinergics, inhibiting muscarinic receptor activation, is an effective bronchodilator therapy in COPD.

Genes encoding five muscarinic receptor subtypes are present in the human genome $\left(M_{1}-M_{5}\right)$. The $M_{1}, M_{2}$ and $\mathrm{M}_{3}$ receptors are abundantly expressed in the lungs and have been extensively studied in the context of vagal neurotransmission. Their primary roles are bronchoconstriction and mucus secretion, which are mainly regulated via $\mathrm{M}_{3}$ receptors on airway smooth muscle and glands, respectively. Furthermore, the $\mathrm{M}_{1}$ receptor facilitates neurotransmission in the parasympathetic ganglia and regulates electrolyte and water secretion by mucus-producing cells. The $\mathrm{M}_{2}$ receptor is an autoinhibitory pre-junctional receptor on vagal nerves inhibiting acetylcholine release and an abundant post-junctional receptor on airway smooth muscle [5-7].

It is now known that acetylcholine can exert many additional, non-neuronal effects in the airways. Muscarinic receptors are expressed by almost all cell types in the lungs, including epithelial and inflammatory cells $[8,9]$. Strikingly, these cells express all the necessary components to synthesise and release acetylcholine by themselves, including choline acetyl transferase (ChAT), the synthesising enzyme of acetylcholine. This is referred to as non-neuronal acetylcholine and may contribute to airway inflammation [9-11]. Indeed, in vitro studies have revealed a variety of effects of acetylcholine on these cell types [11], including an induced release of the potent neutrophil chemoattractants IL- 8 and leukotriene (LT) $B_{4}$ from airway epithelial, smooth muscle and inflammatory cells [12-15]. Recent evidence from in vivo studies also demonstrated a pro-inflammatory role for acetylcholine under pathophysiological conditions. In a cigarette smoke-induced mouse model of COPD, tiotropium partly prevented the increase in total cells and neutrophils in the bronchoalveolar lavage fluid (BALF). Furthermore, the release of various cytokines, including IL-6, keratinocyte-derived chemokine (KC, the mouse orthologue of IL-8), $\mathrm{LTB}_{4}$ and MCP-1, was inhibited by tiotropium [16]. Our group recently demonstrated that lipopolysaccharide-induced neutrophilic inflammation could be completely prevented by tiotropium in a guinea pig model of COPD [17]. Similar findings indicating a pro-inflammatory role for acetylcholine have been observed in animal models of asthma, acute lung injury and fibrosis [6].

Together, these studies clearly indicate a role for acetylcholine in inflammation, which may have implications for anticholinergic therapy in patients with COPD. Therapy with anticholinergics is presently focused on the $\mathrm{M}_{3}$ receptor, since this receptor subtype mediates bronchoconstriction. Although in vitro studies suggest a role for the $\mathrm{M}_{3}$ receptor in cytokine release $[12,18]$, no information is available with respect to the muscarinic receptor subtypes involved in the pro-inflammatory effects of acetylcholine in vivo. Therefore, the aim of this study was to investigate the role of the $\mathrm{M}_{1}, \mathrm{M}_{2}$ and $\mathrm{M}_{3}$ receptor subtypes in cigarette smoke-induced airway inflammation using muscarinic receptor subtype-deficient mice. We hypothesised that the $\mathrm{M}_{3}$ receptor plays a predominant pro-inflammatory role. In order to study this, we assessed inflammatory cell counts and mediator release in the lavage fluid. Furthermore, we analysed the expression of genes associated with remodelling.

\section{Methods}

Animals

Homozygous, inbred, specific-pathogen-free breeding colonies of $\mathrm{M}_{1}{ }^{-/-}, \mathrm{M}_{2}{ }^{-/-}$and $\mathrm{M}_{3}^{-/-}$mice and C57Bl/ $6 \mathrm{NTac}$ wild-type mice with the same genetic background were obtained from Taconic (Ry, Denmark). The $\mathrm{M}_{1}{ }^{-/-}, \mathrm{M}_{2}^{-1-}$ and $\mathrm{M}_{3}^{-/-}$mice used were generated on a $129 \mathrm{~Sv} / \mathrm{J}$ background and backcrossed for $\geqslant 10$ generations onto the $\mathrm{C} 57 \mathrm{Bl} / 6 \mathrm{NTac}$ background [19-21]. Knock-out animals did not differ from wild-type controls in overall health, fertility and longevity [19-21], although the weight of $\mathrm{M}_{3}{ }^{-/-}$mice was less than that of wild-type mice (online supplementary table E1). Exposure to cigarette smoke did not affect the weight of the mice (online supplementary table E1). Animals were housed conventionally under a 12-h light-dark cycle and received food and water ad libitum. All experiments were performed in accordance 
FIGURE 1 Experimental procedure. Male C57Bl/6NTac mice were exposed to cigarette smoke twice daily on four consecutive days by whole body exposure. $16 \mathrm{~h}$ after the last smoke exposure a bronchoalveolar lavage was performed and lungs were harvested for lung tissue homogenates and cryosection. Cig: cigarette(s); TGF: transforming growth factor; ChAT: choline acetyl transferase.

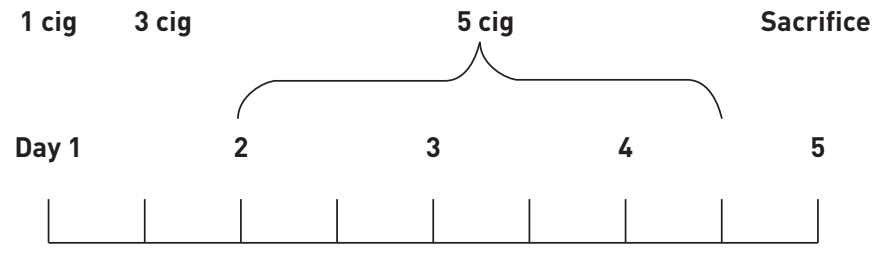

Bronchoalveolar lavage fluid Inflammatory cells Cytokine release Muscarinic receptor gene expression

Lung tissue homogenates

Gene expression of the non-neuronal cholinergic system

Gene expression of:

TGF- $\beta 1$

Collagen and fibronectin

MUC5AC

\section{Cryosections}

ChAT expression

with the national guidelines and approved by the University of Groningen Committee for Animal Experimentation (Groningen, the Netherlands).

\section{Animal model}

Male mice ( $n=8-9$ per group, 10-12 weeks old) were exposed to cigarette smoke from Kentucky 3R4F research cigarettes (Tobacco Research Institute, University of Kentucky, Lexington, KY, USA) on four consecutive days by whole-body exposure. Each cigarette was smoked without a filter in 5 min at a rate of $5 \mathrm{~L} \cdot \mathrm{h}^{-1}$ in a ratio with $60 \mathrm{~L} \cdot \mathrm{h}^{-1}$ air using a peristaltic pump (45 rpm) (323 E/D; Watson Marlow, Rotterdam, The Netherlands). Cigarette smoke was directly distributed into a 6-L perspex box. On day 1, mice were exposed to the mainstream smoke of one cigarette in the morning and three cigarettes in the afternoon. On days 2-4, mice were exposed to five cigarettes in the morning and five in the afternoon (fig 1). Control animals were handled in the same way but exposed to fresh air only. Because of the capacity of the experimental set-up, not all animals used for this study could be included in a single experiment. Therefore, experiments were performed on three occasions $(n=19-24$ animals per experiment). Air- and cigarette smoke-exposed wild-type mice were included in every experiment to minimise variability. $16 \mathrm{~h}$ after the last cigarette smoke exposure, animals were euthanised by intraperitoneal pentobarbital injection (400 $\mathrm{mg} \cdot \mathrm{kg}^{-1}$; University Medical Center Groningen, Groningen, The Netherlands), after which the lungs were immediately lavaged, resected and snap frozen in liquid nitrogen.

\section{Muscarinic antagonist administration}

In a substudy, the $\mathrm{M}_{3}$ receptor selective antagonist 4-DAMP (1,1-dimethyl-4-diphenylacetoxypiperidinium iodide) $\left(1 \mathrm{mg} \cdot \mathrm{kg}^{-1}\right)$ was administered to wild-type mice $(\mathrm{n}=7)$ by i.p. injection, 30 min prior to each cigarette smoke exposure. The same experimental protocol was used as described above.

\section{Analysis of BALF}

After euthanising the mice, the lungs were gently lavaged through a tracheal cannula with $1 \mathrm{~mL}$ PBS containing 5\% bovine serum albumin and protease inhibitors (inhibiting chymotrypsin, thermolysin, papain, pronase, pancreatic extract and trypsin; F. Hoffman-La Roche, Basel, Switzerland) and another four times with $1 \mathrm{~mL}$ PBS. Cells were pelleted and the supernatants of the first fraction were stored at $-20^{\circ} \mathrm{C}$ for measurement of cytokines and growth factors by ELISA. For each animal individually, bronchoalveolar lavage cells of the different fractions were combined, resuspended in $500 \mu \mathrm{L}$ PBS, and total cell numbers were determined. For cytological examination, cytospin preparations were stained with May-Grünwald and Giemsa (both Sigma, St Louis, MO, USA) and a differential cell count was performed by counting $\geqslant 400$ cells in duplicate in a blinded fashion. KC, MCP-1, IL-6, IL-1 $\beta$, IL-17, TNF- $\alpha$ and VEGF release was determined in BALF supernatants by a MILLIPLEX assay (Millipore, Billerica, MA, USA). TGF- $\beta$ in BALF was determined by an ELISA kit (R\&D Systems, Minneapolis, MN, USA) according to the manufacturer's instructions. 
a)
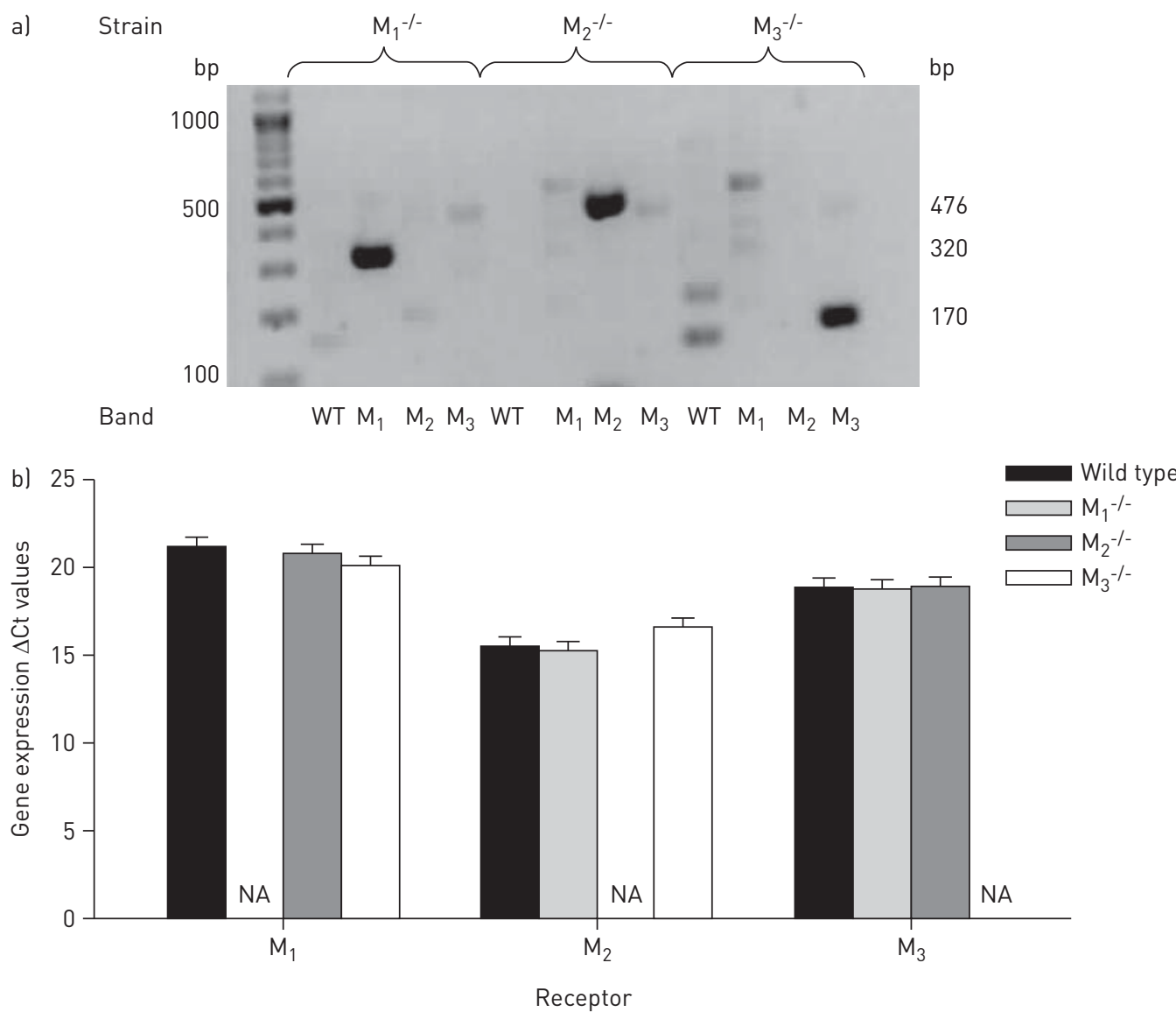

FIGURE 2 Characterisation of the mice. a) SYBR Safe (Invitrogen, Eugene, OR, USA) -stained agarose gel showing the PCR products for genotyping, including the wild-type, muscarinic $\mathrm{M}_{1}, \mathrm{M}_{2}$ and $\mathrm{M}_{3}$ receptor bands for $\mathrm{M}_{1}{ }^{-1-}, \mathrm{M}_{2}{ }^{-1-}$ and $\mathrm{M}_{3}{ }^{-/-}$mice, respectively. b) Gene expression of muscarinic receptors in lung tissue homogenates depicted as amplification cycle number $(\mathrm{Ct})$ values corrected for $18 \mathrm{~S}$ ( $\mathrm{n}=5$ mice per group). Note that data are expressed as $\Delta \mathrm{Ct}$ values, thus lower values mean higher expression levels and every unit lower on the y-axis represents a two-fold increase in expression. NA: not applicable.

\section{ChAT staining}

To identify ChAT expression, 5 - $\mu$ m-thick cryosections $(n=4)$ were stained with a specific rabbit anti-ChAT antibody provided by W. Kummer (Institute for Anatomy and Cell Biology, Justus-Liebig-University, Giessen, Germany). The antibody was visualised using a horseradish peroxidase-linked secondary antibody and diaminobenzidine $\left(1 \mathrm{mg} \cdot \mathrm{mL}^{-1}\right)$. Airways within each section were photographed digitally.

\section{Analysis of gene expression in lung tissue}

Total RNA was extracted from lung tissue (right superior lobe) or bronchalveolar lavage cells using the RNeasy Mini Kit (Qiagen, Venlo, the Netherlands) according to the manufacturer's instructions. Lung homogenates were prepared by pulverising the tissue under liquid nitrogen. Equal amounts of total mRNA were then reverse transcribed and cDNA was subjected to real-time quantitative PCR (Westburg, Leusden, the Netherlands). Real-time PCR was performed with denaturation at $94^{\circ} \mathrm{C}$ for $30 \mathrm{~s}$, annealing at $59^{\circ} \mathrm{C}$ for $30 \mathrm{~s}$ and extension at $72^{\circ} \mathrm{C}$ for $30 \mathrm{~s}$ for 40 cycles followed by $10 \mathrm{~min}$ at $72^{\circ} \mathrm{C}$. Real-time PCR data were analysed using the comparative cycle threshold method. The amount of the target gene was normalised to the endogenous reference gene $18 \mathrm{~S}$ ribosomal RNA. Several other housekeeping genes, including $\beta 2$-microglobulin and glyceraldehyde 3-phosphate dehydrogenase (GAPDH), were tested for the influence of the experimental procedure on the expression. The expression of all housekeeping genes, including 18S, was stable in the tested conditions. The specific forward and reverse primers used are listed in online supplementary table E2.

\section{Statistical analysis}

Data are presented as mean \pm SEM. Statistical differences between means were calculated using one- or twoway ANOVA, followed by Newman-Keuls multiple comparison tests. Differences were considered significant at $\mathrm{p}<0.05$. 
a)

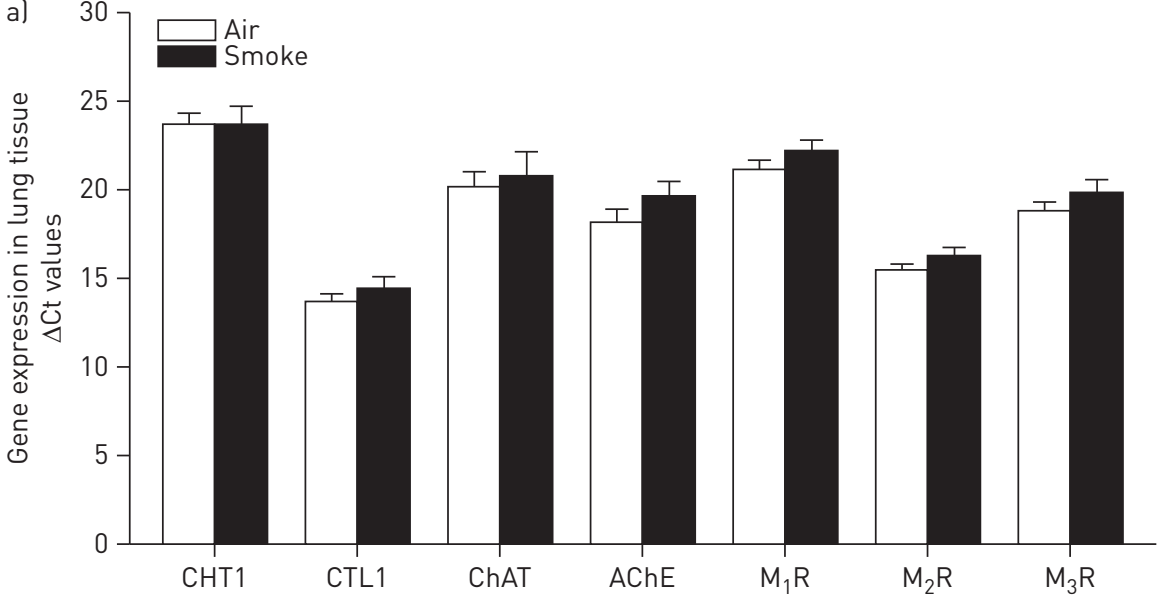

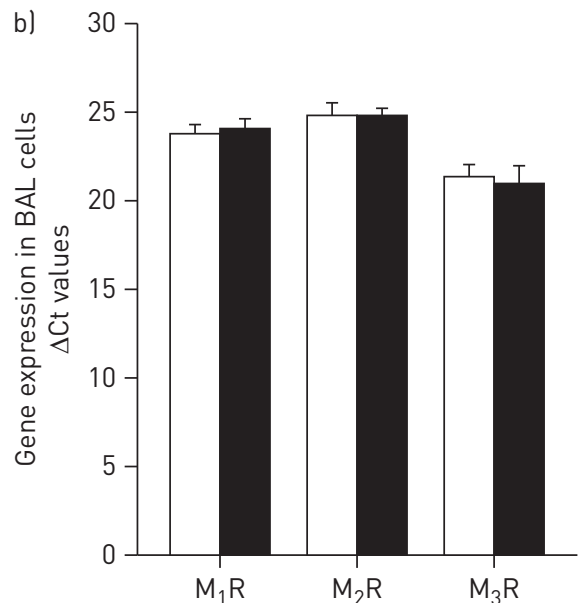

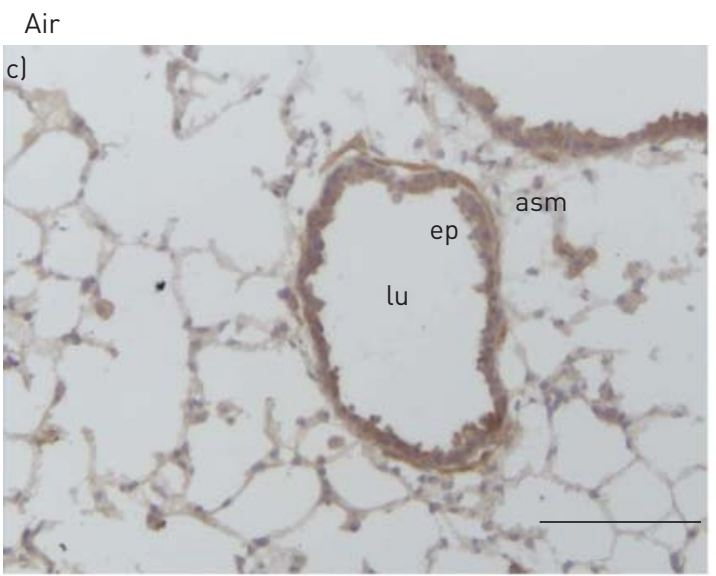

Smoke
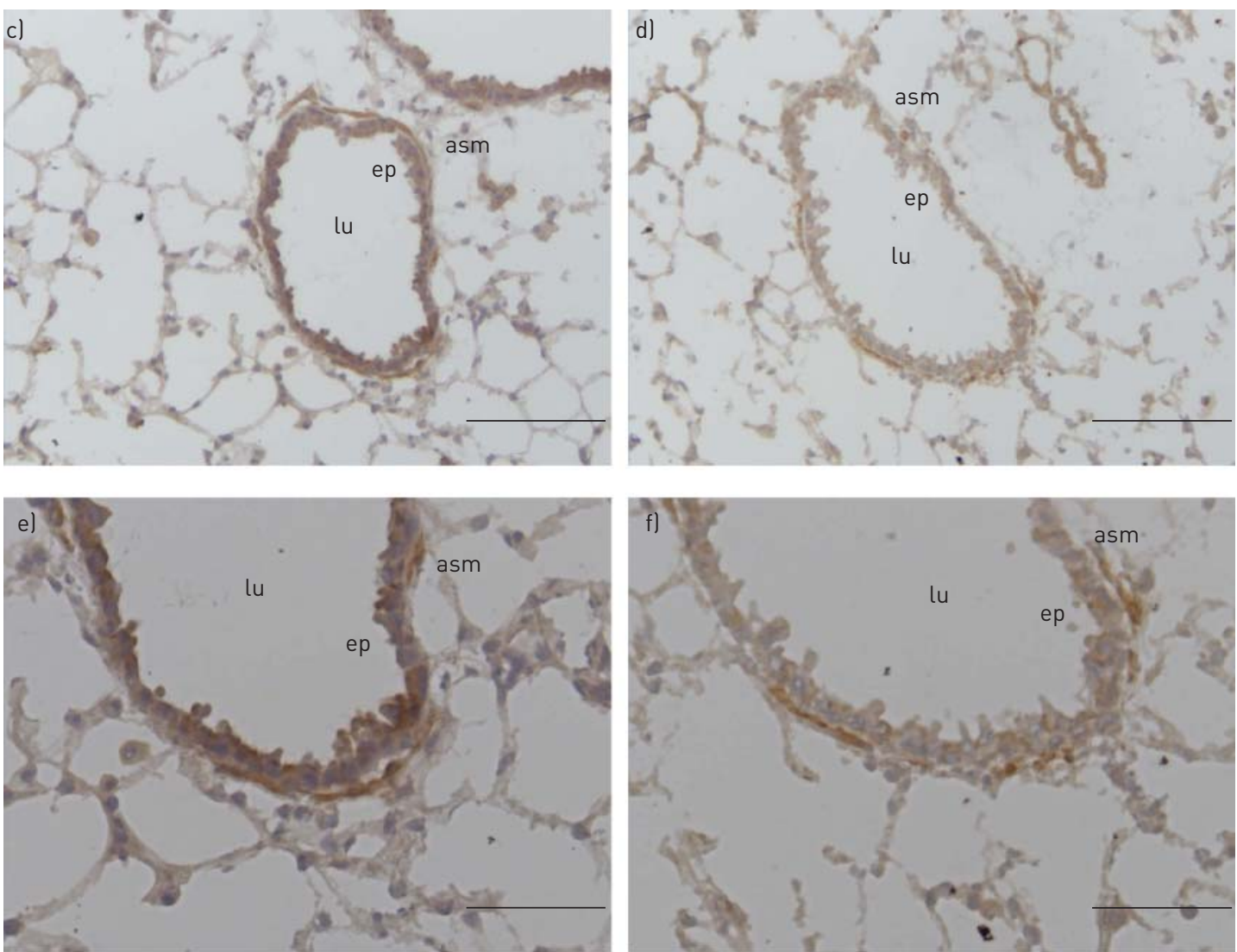

FIGURE 3 Effect of cigarette smoke exposure on the expression of the non-neuronal cholinergic system. Mice were treated as described in figure $1.16 \mathrm{~h}$ after the last smoke exposure lung tissue and bronchoalveolar lavage fluid (BALF) were harvested. Gene expression in a) lung tissue homogenates and b) bronchoalveolar lavage cells was analysed ( $\mathrm{n}=3-5$ mice per group). Amplification cycle number $(\mathrm{Ct})$ values corrected for $18 \mathrm{~S}$ are depicted, expressed as mean \pm SEM. Note that data are expressed as $\Delta \mathrm{Ct}$ values, thus lower values mean higher expression levels and every unit lower on the y-axis represents a two-fold increase in expression. Highaffinity choline transporter (CHT)1, choline transporter like protein (CTL)1, choline acetyl transferase (ChAT), acetylcholinesterase (AChE), muscarinic $\mathrm{M}_{1}$ receptor $\left(M_{1} R\right), M_{2}$ receptor $\left(M_{2} R\right)$ and $M_{3}$ receptor $\left(M_{3} R\right)$. c-f) Cryosections of wild-type mice exposed to air and smoke stained for ChAT. A representative picture of $\mathrm{n}=4$ animals is shown. lu: airway lumen; ep: epithelium; asm: airway smooth muscle. $\mathrm{c}$ and d) Scale bars $=100 \mu \mathrm{m}$; e and f) Scale bars $=50 \mu \mathrm{m}$.

\section{Results}

Characterisation of the mice

The genotypes of the knockout mice were confirmed by PCR analysis of mouse ear DNA (fig. 2a and online supplementary table E3). We also examined whether the deletion of one muscarinic receptor gene affected the expression levels of the two other muscarinic receptors expressed in the lung. As shown in figure $2 b$, 

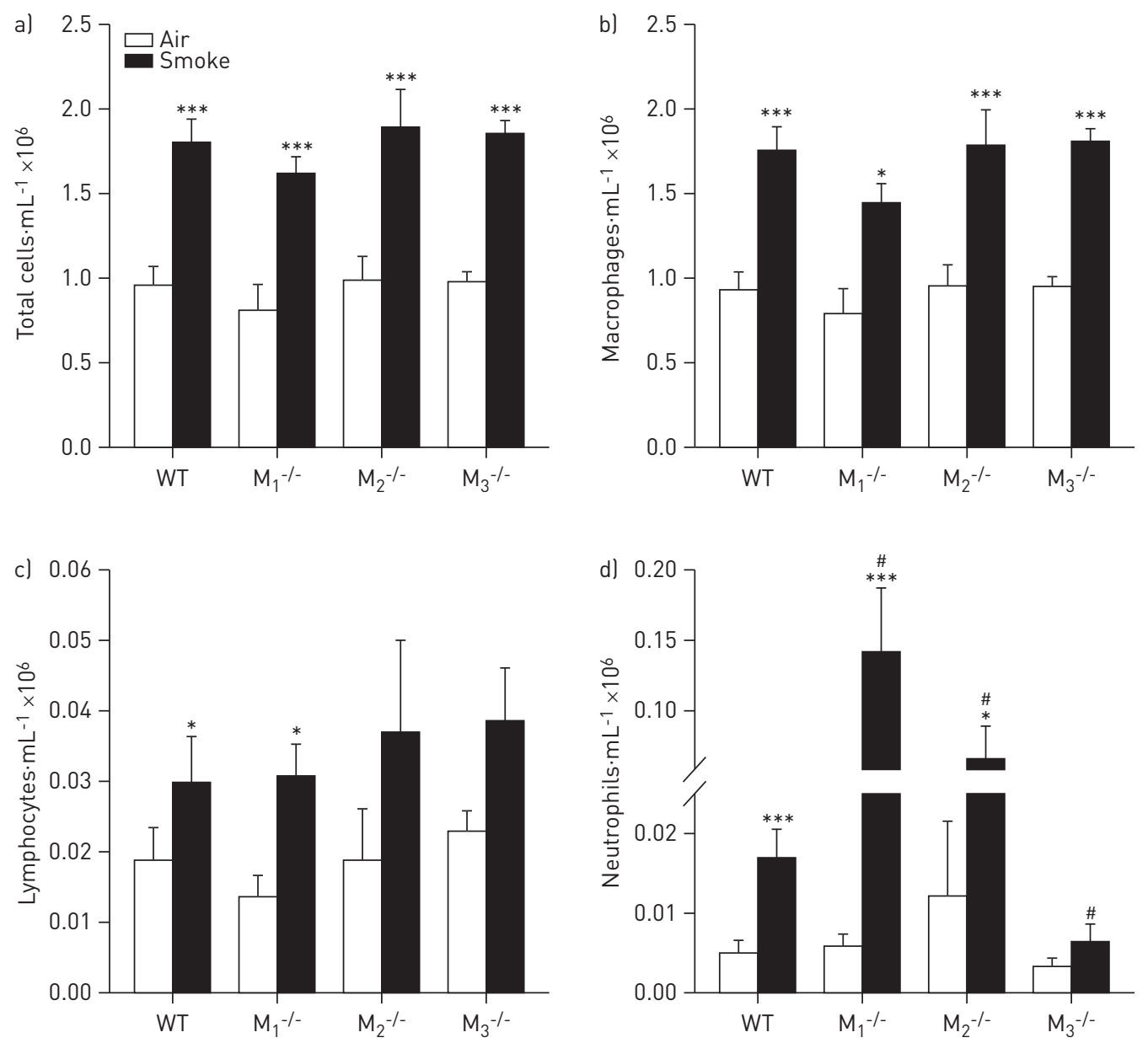

FIGURE 4 Inflammatory cell counts after cigarette smoke exposure. Mice were treated as described in figure $1.16 \mathrm{~h}$ after the last smoke exposure bronchoalveolar lavage was performed and a) total cells, b) macrophages, c) lymphocytes and d) neutrophils were determined in the bronchoalveolar lavage fluid. Data are presented as mean \pm SEM. $n=8-9$ mice per group. Data were analysed using two-way ANOVA: a) total cells $F[1,56]=89.25, \mathrm{p}<0.001$ for sham versus smoke treatment; $F[3,56]=1.233, p=0.307$ for the muscarinic receptor subtypes; $F[3,56]=0.0493, p=0.985$ for the interaction; b) macrophages $F[1,56]=78.60, p<0.001$ for sham versus smoke treatment; $F[3,56]=1.93, p=0.135$ for the muscarinic receptor subtypes; $\mathrm{F}[3,56]=0.27, \mathrm{p}=0.849$ for the interaction; $\mathrm{c}$ ) lymphocytes $\mathrm{F}[1,56]=12.70, \mathrm{p}<0.001$ for sham versus smoke treatment; $F[3,56]=0.587, p=0.587$ for the muscarinic receptor subtypes; $F[3,56]=0.05, p=0.984$ for the interaction; d) neutrophils $F[1,56]=17.65, \mathrm{p}<0.001$ for sham versus smoke treatment; $F[3,56]=6.37, \mathrm{p}<0.001$ for the muscarinic receptor subtypes; $\mathrm{F}[3,56]=5.90, \mathrm{p}=0.001$ for the interaction. WT: wild type. Individual comparisons were made using a Student-Newman-Keuls multiple comparisons post hoc test. ${ }^{*}: \mathrm{p}<0.05$; ${ }^{* * *}: \mathrm{p}<0.001$ compared to airexposed control mice; ${ }^{*}: \mathrm{p}<0.05$ compared to wild-type cigarette smoke-exposed mice.

no such compensatory changes were observed. Muscarinic receptors were highly expressed in lung tissue homogenates, with $\mathrm{M}_{2}>\mathrm{M}_{3}>\mathrm{M}_{1}$ (fig. 2b).

\section{The non-neuronal cholinergic system}

It has been proposed that the non-neuronal cholinergic system (NNCS) might contribute to airway inflammation [11]. To investigate the effect of cigarette smoke exposure, gene expression of different components of the cholinergic system was analysed in lung tissue homogenates of wild-type mice, including the choline transporters high-affinity choline transporter-1 and choline transporter-like protein-1, the acetylcholine synthesising enzyme ChAT, the acetylcholine degrading enzyme acetylcholinesterase and the different muscarinic receptor subtypes. As depicted in figure 3a, these components were expressed in the murine lungs and cigarette smoke exposure did not affect their expression level. Similarly, the muscarinic receptor expression in the bronchoalveolar lavage cells from wild-type mice was not altered after cigarette smoke exposure (fig. $3 b$ ). In lung tissue, $M_{2}$ receptors were expressed at the highest levels $\left(M_{2}>M_{3}>M_{1}\right)$, whereas in the cells from the BALF, $M_{3}$ receptors were expressed at the highest levels $\left(M_{3} R>M_{1} R>M_{2} R\right)$ (online supplementary fig. E1). ChAT expression, detected by immunohistochemical staining, was localised 

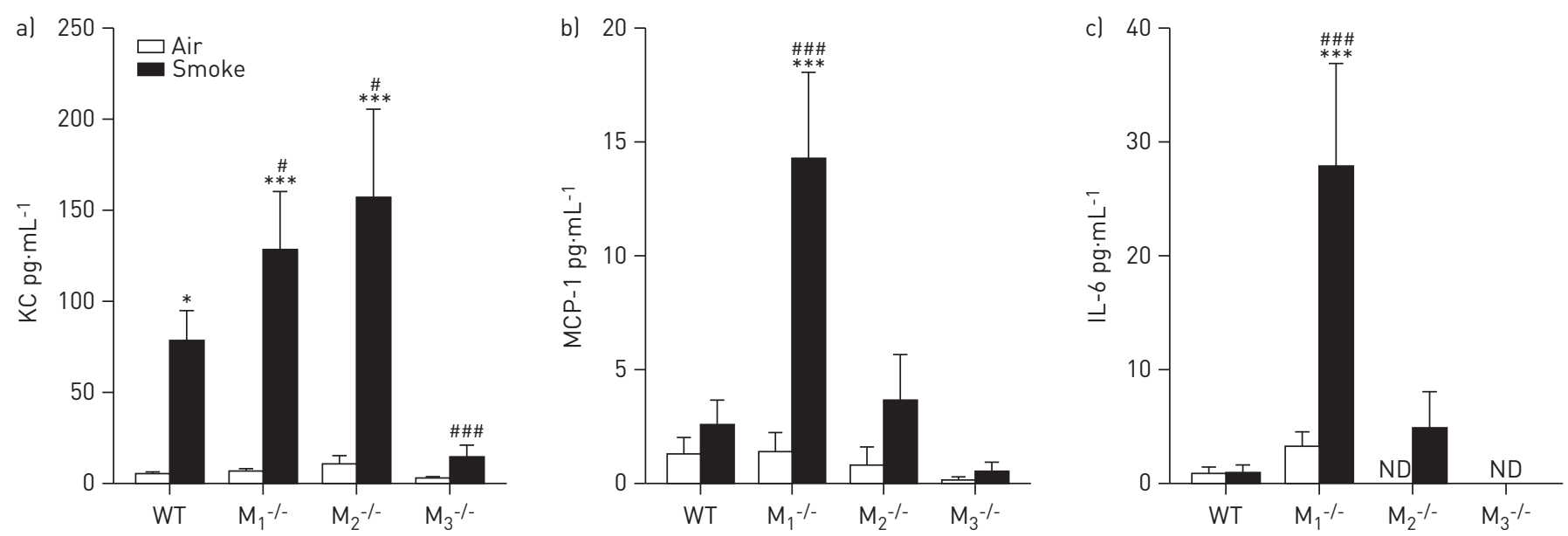

FIGURE 5 Inflammatory cytokine release after cigarette smoke exposure. Mice were treated as described in figure $1.16 \mathrm{~h}$ after the last smoke exposure a bronchoalveolar lavage was performed. Release of a) keratinocyte-derived chemokine (KC); b) monocyte chemotactic protein (MCP)-1; and c) interleukin (IL)-6 in bronchoalveolar lavage fluid was determined. Data are presented as mean \pm SEM. $n=8-9$ mice per group. Data were analysed using two-way ANOVA: a) KC $\mathrm{F}[1,56]=32.85, \mathrm{p}<0.001$ for sham versus smoke treatment; $\mathrm{F}[3,56]=4.40, \mathrm{p}=0.008$ for the muscarinic receptor subtypes; $\mathrm{F}[3,56]=3.61, \mathrm{p}=0.019$ for the interaction; b) MCP-1 $\mathrm{F}[1,56]=13.91, \mathrm{p}<0.001$ for sham versus smoke treatment; $\mathrm{F}[3,56]=7.49, \mathrm{p}<0.001$ for the muscarinic receptor subtypes; $\mathrm{F}[3,56]=5.89$, $\mathrm{p}=0.001$ for the interaction; c) IL- $6 \mathrm{~F}[1,56]=9.32, \mathrm{p}=0.003$ for sham versus smoke treatment; $\mathrm{F}[3,56]=8.69, \mathrm{p}<0.001$ for the muscarinic receptor subtypes; $\mathrm{F}[3,56]=5.63, \mathrm{p}=0.002$ for the interaction. WT: wild type; ND: not detectable. Individual comparisons were made using a Student-Newman-Keuls multiple

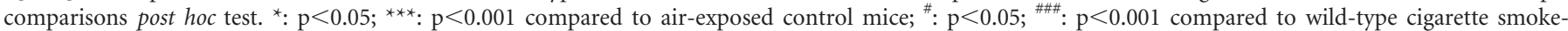
exposed mice.

to the epithelium and smooth muscle layer of the airway wall in wild-type mice (fig. $3 \mathrm{c}$ ). Exposure to cigarette smoke did not alter the expression or localisation of ChAT (fig. 3c).

\section{Cigarette smoke-induced inflammatory cell recruitment}

To study the contribution of muscarinic receptor subtypes to cigarette smoke-induced airway inflammation, cell counts were determined in the BALF of wild-type, $\mathrm{M}_{1}{ }^{-/-}, \mathrm{M}_{2}{ }^{-/-}$and $\mathrm{M}_{3}{ }^{-/-}$mice. All mice exposed to cigarette smoke had a two-fold increase in the number of inflammatory cells compared to air-exposed control animals (fig. 4a). The predominant cell type after cigarette smoke exposure was the macrophage, which almost doubled in number in all strains (fig. 4b). Only small increases in lymphocytic infiltration were observed after cigarette smoke exposure, which were comparable in all strains (fig. 4c). However, neutrophilic infiltration showed significant differences between the strains (fig. 4d). A four-fold increase in the amount of neutrophils was observed in wild-type mice compared to air-exposed animals. However, in $\mathrm{M}_{1}^{-/-}$and $\mathrm{M}_{2}^{-/-}$mice, the increase in neutrophil number upon cigarette smoke exposure was much higher, up to 24 -fold in $\mathrm{M}_{1}^{-/-}$mice. In striking contrast, no significant increase in neutrophil numbers was observed in $\mathrm{M}_{3}{ }^{-/-}$mice after cigarette smoke exposure compared to air-exposed control animals (figure $4 d$ ).

\section{Cigarette smoke-induced cytokine release}

Subsequently, inflammatory cytokine release in BALF was determined. Levels of KC in BALF of wild-type mice exposed to cigarette smoke were 15-fold higher compared to air-exposed animals (fig. 5a). No significant differences in MCP-1 and IL-6 release were observed in cigarette smoke-exposed wild-type mice (fig. $5 \mathrm{~b}$ and c). In $\mathrm{M}_{1}{ }^{-1-}$ mice, cigarette smoke-exposed mice had higher levels of KC, MCP-1 and IL-6 compared to air-exposed mice. Interestingly, the concentration of all these cytokines was significantly higher when compared to wild-type cigarette smoke-exposed mice. In cigarette smoke-exposed $\mathrm{M}_{2}{ }^{-/-}$mice, KC release was also significantly higher, both compared to air-exposed mice and to wild-type cigarette smoke-exposed mice, whereas MCP-1 and IL-6 release were not significantly different. In $\mathrm{M}_{3}{ }^{-/-}$mice, no increase in the release of any of these cytokines was observed after cigarette smoke exposure, and $\mathrm{KC}$ release was significantly lower compared to wild-type cigarette smoke-exposed mice (fig. 5). Levels of IL-17, IL-1 $\beta$ and TNF- $\alpha$ were below detection limit in all strains (not shown).

\section{Cigarette smoke-induced growth factor and extracellular matrix expression}

We next determined the release of the growth factors TGF- $\beta 1$ and VEGF in the BALF. Small increases in TGF- $\beta 1$ protein release were observed in all strains after cigarette smoke exposure (1.4-2.0-fold), which was significant in wild-type mice (fig. 6a). Remarkably, there was significantly less TGF- $\beta 1$ in the BALF of $\mathrm{M}_{3}{ }^{-/-}$ mice compared to wild-type mice, irrespective of air or cigarette smoke exposure $(56 \%$ and $46 \%$ lower, 

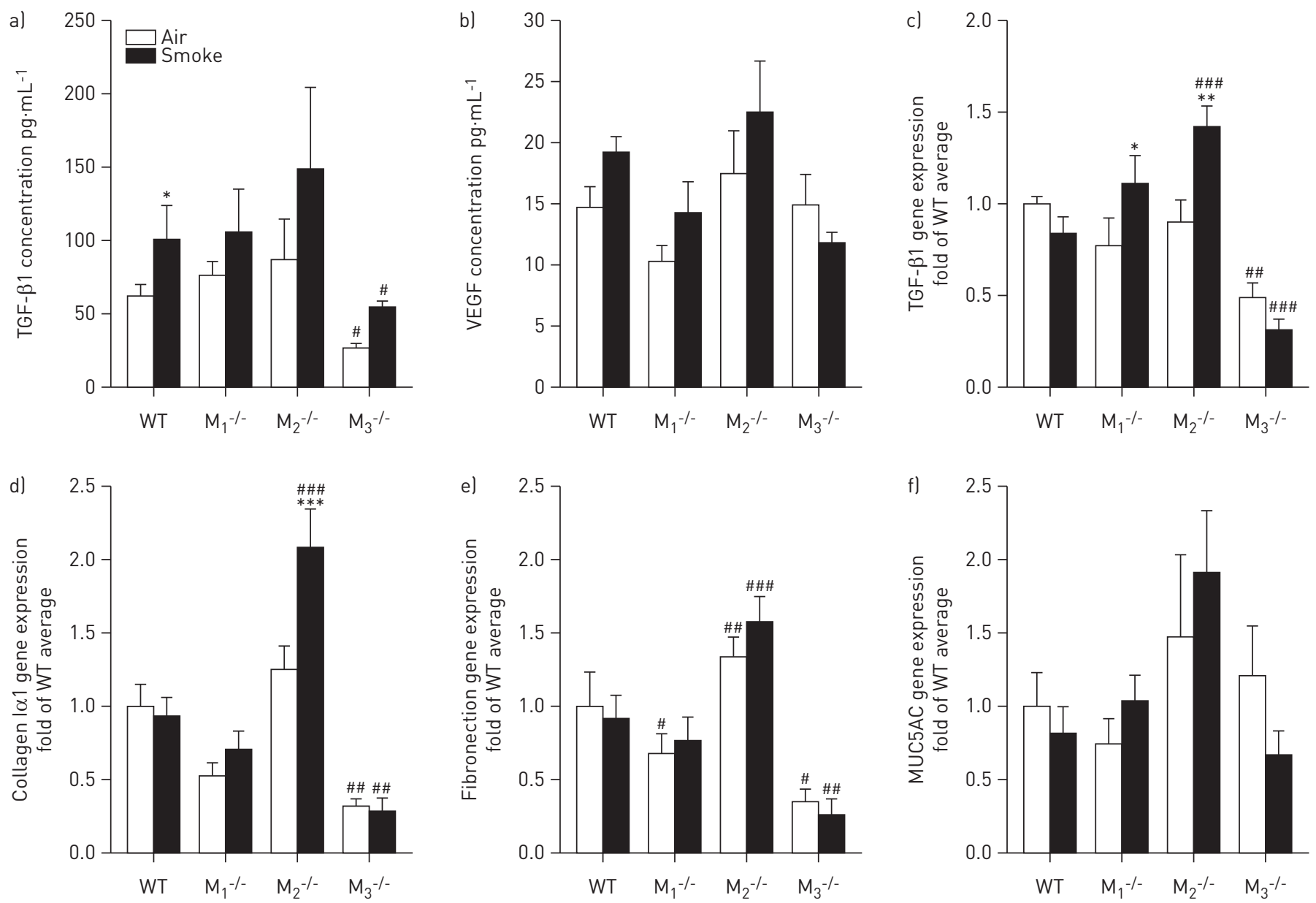

FIGURE 6 Parameters of remodelling after cigarette smoke exposure. Mice were treated as described in figure $1.16 \mathrm{~h}$ after the last smoke exposure a bronchoalveolar lavage was performed and lungs were collected. Release of a) transforming growth factor (TGF)- $\beta 1$ and b) vascular endothelial growth factor (VEGF) in bronchoalveolar lavage fluid was determined. In lung tissue homogenates, gene expression of c) TGF- $\beta 1$, d) collagen I $\alpha 1$, e) fibronectin and f) MUC5AC was determined. Data are presented as mean \pm SEM. $n=8-9$ mice per group. Statistics were performed on log-transformed data. Data were analysed using two-way ANOVA: a) TGF- $\beta 1$ protein $F[1,56]=4.72, p=0.034$ for sham versus smoke treatment; $F[3,56]=3.10, p=0.034$ for the muscarinic receptor subtypes; $F[3,56]=0.18, p=0.908$ for the interaction; b) VEGF protein $F[1,56]=2.15, p=0.148$ for sham versus smoke treatment; $F[3,56]=3.84, p=0.014$ for the muscarinic receptor subtypes; $\mathrm{F}[3,56]=1.13, \mathrm{p}=0.347$ for the interaction; $\mathrm{c}$ ) TGF- $\beta 1$ mRNA $\mathrm{F}[1,56]=3.16$, $\mathrm{p}=0.081$ for sham versus smoke treatment; $\mathrm{F}[3,56]=18.38, \mathrm{p}<0.001$ for the muscarinic receptor subtypes; $\mathrm{F}[3,56]=5.66, \mathrm{p}=0.002$ for the interaction; $\mathrm{d}$ ) collagen $\mathrm{I} \alpha 1 \mathrm{~F}[1,56]=6.91, \mathrm{p}=0.011$ for sham versus smoke treatment; $F[3,56]=43.02, p<0.001$ for the muscarinic receptor subtypes; $F[3,56]=5.97, p=0.001$ for the interaction; e) fibronectin $F[1,56]=0.03$, $p=0.862$ for sham versus smoke treatment; $F[3,56]=36.10, p<0.001$ for the muscarinic receptor subtypes; $F[3,56]=1.37, p=0.262$ for the interaction; $f$ ) MUC5AC F $[1,56]=4.95 \times 10^{-4}, p=0.982$ for sham versus smoke treatment; $F[3,56]=3.19, p=0.030$ for the muscarinic receptor subtypes; $F[3,56]=1.04, p=0.381$ for the interaction. Individual comparisons were made using a Student-Newman-Keuls multiple comparisons post hoc test. WT: wild-type. ${ }^{*}: \mathrm{p}<0.05$; ${ }^{* *}$ : $\mathrm{p}<0.01$; ${ }_{* * *}: \mathrm{p}<0.001$ compared to air-exposed control mice; ${ }^{\#}: \mathrm{p}<0.05 ;{ }^{\# \#}: \mathrm{p}<0.01 ;{ }^{\# \# \#}: \mathrm{p}<0.001$ compared to WT control mice.

respectively). VEGF release was not altered (fig. 6b). Expression of TGF- $\beta 1$ at the mRNA level in lung tissue of $\mathrm{M}_{3}{ }^{-/-}$mice was reduced to a similar extent compared to protein levels (fig. $6 \mathrm{~b}$ ). At the transcriptional level, TGF- $\beta 1$ expression was significantly increased 1.4-fold in $\mathrm{M}_{1}{ }^{-/-}$mice and 1.7-fold in $\mathrm{M}_{2}{ }^{-/-}$mice after cigarette smoke exposure (fig. 6c).

In addition, we analysed the gene expression of the matrix proteins collagen $I \alpha 1$ and fibronectin in lung tissue. No increased expression after cigarette smoke exposure was observed (fig. $6 \mathrm{~d}$ and e), with the exception of collagen $\mathrm{I} \alpha 1$ in $\mathrm{M}_{2}{ }^{-/-}$mice, which was increased after cigarette smoke exposure. Furthermore, expression levels of collagen $\mathrm{I} \alpha 1$ and fibronectin were higher in cigarette smoke-exposed $\mathrm{M}_{2}^{-/-}$mice compared to cigarette smoke-exposed wild-type mice. In line with the findings for TGF- $\beta 1$, both matrix proteins were expressed at a significantly lower level in $\mathrm{M}_{3}{ }^{-/-}$mice compared to wild-type mice, irrespective of air or cigarette smoke exposure (68\% lower and $65 \%$ lower for collagen $I \alpha 1$ and fibronectin, respectively). This was confirmed at the protein level for fibronectin, which was $38.6 \pm 8.9 \%$ lower in $\mathrm{M}_{3}{ }^{-/}$ mice than in wild-type mice $(\mathrm{p}<0.05)$. Finally, cigarette smoke exposure had no significant effect on MUC5AC gene expression in any of the analysed strains (fig. 6f). 

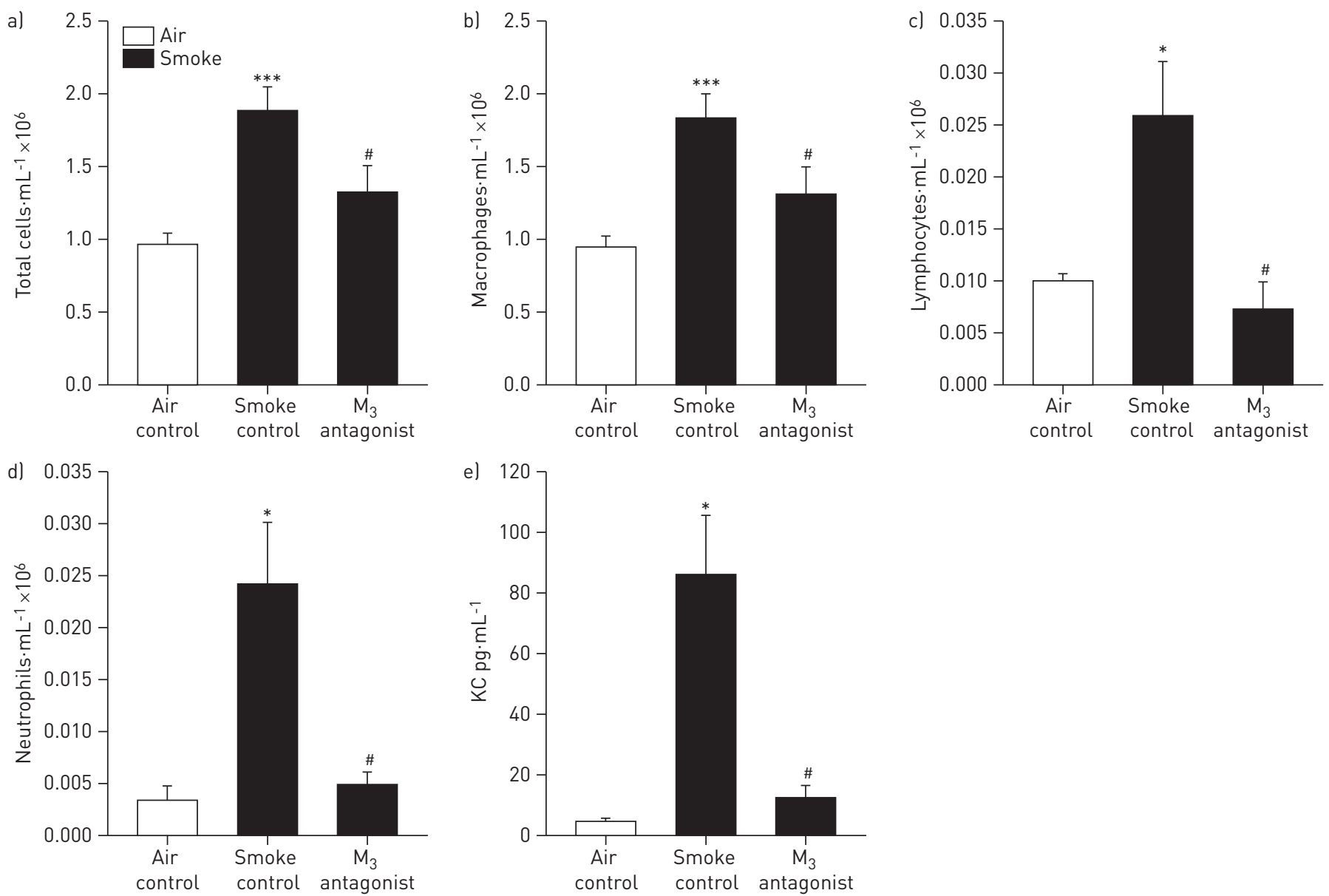

FIGURE 7 Cigarette smoke-induced inflammation after pretreatment with 4-DAMP (1,1-dimethyl-4-diphenylacetoxypiperidinium iodide). The same experimental model was used as described in figure 1; however, prior to each smoke exposure mice were treated with the selective muscarinic $\mathrm{M}_{3}$ antagonist 4DAMP. $16 \mathrm{~h}$ after the last smoke exposure a bronchoalveolar lavage was performed and a) total cells, b) macrophages, c) lymphocytes, d) neutrophils and e) keratinocyte-derived chemokine (KC) release were determined in the bronchoalveolar lavage fluid. Results are expressed as mean \pm SEM. $n=7-13$ mice per group. Data were analysed using one-way ANOVA: a) total cells $\mathrm{F}[2,30]=12.98, \mathrm{p}<0.001$ between groups; $\mathrm{b}$ ) macrophages $\mathrm{F}[2,30]=11.92$, $\mathrm{p}<0.001$ between groups; $\mathrm{c}$ ) lymphocytes $\mathrm{F}[2,30]=5.87, \mathrm{p}=0.007$ between groups; d) neutrophils $\mathrm{F}[2,30]=8.23, \mathrm{p}=0.001$ between groups; e) $\mathrm{KC} \mathrm{F}[2,30]=9.53$, $\mathrm{p}<0.001$ between groups. Individual comparisons were made using a Student-Newman-Keuls multiple comparisons post hoc test. ${ }^{*}: \mathrm{p}<0.05$; ${ }^{* *}$ : $\mathrm{p}<0.001$ compared to air-exposed control mice; ${ }^{*}: \mathrm{p}<0.05$ compared to cigarette smoke-exposed mice.

\section{Inhibition of cigarette smoke-induced inflammation by an $\mathrm{M}_{3}$ antagonist}

To investigate whether the pro-inflammatory role of the $M_{3}$ receptor can also be observed using a pharmacological intervention, wild-type mice were pre-treated with the $M_{3}$ receptor selective antagonist 4DAMP 30 min prior to every cigarette smoke exposure. This resulted in an inhibition of inflammatory cell number in the BALF by $30 \%$ compared to untreated animals (fig. 7a). Similar inhibitory effects of pretreatment with 4-DAMP were observed on macrophage accumulation (fig. 7b), whereas cigarette smokeinduced lymphocytic and neutrophilic inflammation were completely prevented (fig. $7 \mathrm{c}$ and $\mathrm{d}$ ). This was accompanied by the absence of cigarette smoke-induced KC release after pre-treatment with 4-DAMP (fig. 7e).

\section{Discussion}

In this study we demonstrate that the $\mathrm{M}_{3}$ receptor plays a profound pro-inflammatory role in cigarette smoke-induced inflammation and that this is the primary muscarinic receptor subtype involved in the proinflammatory effects of acetylcholine. Inhibition of the $\mathrm{M}_{3}$ receptor, by total knockout of the receptor or by a pharmacological approach, prevented neutrophilic inflammation and cytokine release in the lavage fluid of cigarette smoke-exposed mice. In striking contrast, knockout of the $M_{1}$ and $M_{2}$ receptors resulted in increased neutrophils and cytokine release in the BALF, indicating an anti-inflammatory role of these receptor subtypes in cigarette smoke-induced inflammation. This study is the first to demonstrate the differential regulation of inflammation by muscarinic receptors in vivo and implies an anti-inflammatory role for $\mathrm{M}_{3}$ selective anticholinergics. 
Neutrophils are considered to be one of the major cell types involved in COPD [2].Various studies suggest an important role for acetylcholine in regulating neutrophilic inflammation. Activation of muscarinic receptors can contribute to neutrophil influx by inducing neutrophil chemotactic activity from macrophages $[22,23]$ and $\mathrm{LTB}_{4}$ release from sputum cells of COPD patients [15]. Furthermore, IL-8 is released from epithelial and airway smooth muscle cells in response to muscarinic receptor stimulation [12, 14]. These findings are supported by in vivo studies in which cigarette smoke- and lipopolysaccharide-induced neutrophilia was inhibited by the muscarinic receptor antagonist tiotropium [16, 17].

The regulatory effects of muscarinic receptors appeared to be specific for neutrophils in the muscarinic receptor deficient mice, whereas macrophages and lymphocytes were not altered. Our results on neutrophilic inflammation are in line with various in vitro studies demonstrating that the pro-inflammatory effects of muscarinic receptor activation are mainly dependent on the $\mathrm{M}_{3}$ receptor subtype. Thus, it has been shown that 4-DAMP and DAU5884, $\mathrm{M}_{3}$ receptor selective antagonists, inhibited methacholine and cigarette smoke-induced IL-8 release from airway smooth muscle cells [12]. In addition, alveolar macrophage-mediated migration of neutrophils from COPD patients was inhibited by 4-DAMP [18]. Moreover, the $\mathrm{M}_{3}$ receptor was the primary receptor subtype expressed by inflammatory cells within the BALF as shown in our study. It is also known that inflammatory cells express $M_{3}$ receptors and that this receptor mediates pro-inflammatory effects [8]. We therefore believe that the pro-inflammatory effect of the $\mathrm{M}_{3}$ receptor, as found in our study, is dependent on regulation of cytokine release by structural cells, in combination with direct activation of $\mathrm{M}_{3}$ receptors on inflammatory cells.

In contrast to the findings in $\mathrm{M}_{3}{ }^{-/-}$mice, neutrophilic inflammation was increased in $\mathrm{M}_{2}{ }^{-/-}$mice compared to wild-type mice. The $\mathrm{M}_{2}$ receptor is located pre-junctionally on pre- and post-ganglionic nerves and acts as an inhibitory autoreceptor limiting acetylcholine release [5]. Furthermore, the $\mathrm{M}_{2}$ receptor is expressed post-junctionally by smooth muscle cells and fibroblasts [6, 24]. With acetylcholine acting as a proinflammatory mediator inducing chemokine release from structural and inflammatory cells via the $\mathrm{M}_{3}$ receptor, increased levels of acetylcholine in the $\mathrm{M}_{2}^{-/-}$mice, due to loss of its autoinhibitory role, may therefore explain the observed aggravated neutrophilia. In support of such a role, $\mathrm{M}_{2}$ receptor expression appeared to be low on inflammatory cells in the BALF, but high in lung tissue, suggesting that the effects of $\mathrm{M}_{2}$ receptor deficiency are not due to direct effects on inflammatory cells. The literature supports this notion, indicating that the pro-inflammatory effects of acetylcholine in macrophages, epithelial cells and airway smooth muscle cells are not mediated by $\mathrm{M}_{2}$ receptors [12, 23, 25].

A role for $\mathrm{M}_{2}$ receptors as pre-junctional autoreceptors driving exaggerated acetylcholine release and inflammation has significant implications. Acetylcholine has long been known as a classical neurotransmitter. More recent findings suggest that acetylcholine can also be released from non-neuronal sources, including epithelial, airway smooth muscle and inflammatory cells $[9,10]$. It is not yet known to which extent this non-neuronal acetylcholine affects airway inflammation [11]. The release of non-neuronal acetylcholine is not known to be affected by $\mathrm{M}_{2}$ receptors in an autoinhibitory way. Our data therefore imply an important role for neuronal acetylcholine in cigarette smoke-induced inflammation. Furthermore, we did not find any upregulation of expression of components of the NNCS in the lungs of cigarette smokeexposed mice, in contrast to the previously reported increase in cultured human airway epithelial cells after exposure to cigarette smoke extract [13]. Future studies investigating the contribution of neuronal and nonneuronal acetylcholine to inflammation are clearly warranted.

Surprisingly, neutrophilic inflammation was also enhanced in $\mathrm{M}_{1}{ }^{-/-}$mice. It is well known that $\mathrm{M}_{1}$ receptors facilitate neurotransmission in the parasympathetic ganglia [5]. However, based on this, one would expect that $\mathrm{M}_{1}$ receptor deficiency causes reduced acetylcholine release leading to inhibition of inflammation. ReINHeimer et al. [26] reported that the $\mathrm{M}_{1}$ receptor selective antagonist pirenzepine can antagonise the inhibitory effect of acetylcholine on histamine release from human mast cells. Lack of this inhibitory $\mathrm{M}_{1}$ receptor might explain the increased neutrophil chemotaxis, since mast cell numbers are increased upon smoking and higher in patients with COPD [27, 28]. Alternatively, as the $\mathrm{M}_{1}$ receptor also controls electrolyte and water secretion by airway epithelial cells [29], lack of $M_{1}$ receptor expression may result in a reduced ability of $\mathrm{M}_{1}^{-/-}$mice to clear their lungs of smoke particles after cigarette smoke exposure, leading to aggravated inflammatory and injury responses. The sharp induction of the damage response-associated cytokines IL-6 and MCP-1 in $\mathrm{M}_{1}^{-/-}$mice, which is absent in wild-type mice, supports this hypothesis.

The results of this study on transgenic mice suggest a primary role for the $\mathrm{M}_{3}$ receptor in regulating cigarette smoke-induced inflammation, implying that $\mathrm{M}_{3}$ subtype selectivity of anticholinergics would be beneficial. Indeed, we show that pharmacological inhibition of the $\mathrm{M}_{3}$ receptor using 4-DAMP partly prevented accumulation of inflammatory cells in BALF, accompanied by a strong inhibition of cigarette smoke-induced KC release. 4-DAMP is selective for $M_{3}$ receptors over $M_{2}$ ( $\sim 16$-fold) [7] and, to a lesser extent, $\mathrm{M}_{1}$ receptors (approximately three-fold) [30]. Interestingly, the anti-inflammatory effects of 
pharmacological inhibition of the $\mathrm{M}_{3}$ receptor are more pronounced than effects of knockout of this receptor. Similar discrepant data are reported on muscarinic receptor mediated contraction ex vivo, which can be fully inhibited with a $\mathrm{M}_{3}$ receptor selective antagonist in wild-type mice, whereas only partial inhibition of contraction is observed in $\mathrm{M}_{3}{ }^{-/-}$mice $[31,32]$. Although the mechanism behind this discrepancy is unclear it appears that compensating mechanisms are operative in the knock-out mice that limit the impact of the $\mathrm{M}_{3}$ receptor deficiency.

Although tiotropium is known to be kinetically selective for the $\mathrm{M}_{3}$ receptor (dissociation half-life $27 \mathrm{~h}$ ), it has a dissociation half-life from the $\mathrm{M}_{1}$ receptor of $10.5 \mathrm{~h}$ [33]. Steady-state binding affinity of tiotropium for the $\mathrm{M}_{1}, \mathrm{M}_{2}$ and $\mathrm{M}_{3}$ receptors is not different [34]. The half-life ratio of ipratropium and of aclidinium and glycopyrrolate, two anticholinergics under development, for the $M_{3}$ versus the $M_{1}$ receptor is comparable to tiotropium [33]. Our study suggests that an even more selective compound solely inhibiting $\mathrm{M}_{3}$ receptors is desirable and may lead to improved effects on cigarette smoke-induced inflammation.

Interestingly, in our study basal expression of TGF- $\beta 1$, collagen $I \alpha 1$ and fibronectin was significantly lower in $\mathrm{M}_{3}{ }^{-1-}$ mice compared to wild-type mice. In $\mathrm{M}_{2}{ }^{-1-}$ mice, expression of these components was increased after cigarette smoke exposure. This suggests that in addition to inflammation, acetylcholine regulates important aspects of lung structure via the $\mathrm{M}_{3}$ receptor. Indeed, $\mathrm{M}_{3}$ receptors are expressed by structural cells in the airways, including epithelial cells and airway smooth muscle cells [24]. Moreover, in vitro studies have demonstrated a role for the $\mathrm{M}_{3}$ receptor in the regulation of airway smooth muscle proliferation [35] and in vivo studies have shown a protective effect of anticholinergics on matrix protein deposition $[17,36]$. The exact roles of the individual muscarinic receptor subtypes in this process are not yet clear and remain to be elucidated [6].

Evidence for the pro-inflammatory role of acetylcholine from in vitro and in vivo studies is increasing [6]. However, the translational utility of these observations is not yet clear, since in patients with COPD, effects on inflammation or on the rate of decline in lung function after anticholinergic therapy have not been demonstrated. It is known from the UPLIFT (Understanding Potential Long-term Impacts on Function with Tiotropium) study that the use of tiotropium is associated with a reduction in the number of exacerbations, generally seen as inflammatory events [37]. Patients who have more exacerbations demonstrate increased levels of inflammatory markers at stable state $[38,39]$. However, in two recent studies, no direct evidence for an anti-inflammatory effect was found, since IL-6 and IL-8 levels in the sputum of patients with COPD were not decreased after anticholinergic therapy [40, 41]. However, both studies have substantial limitations as discussed by the authors. In the study by PERNG et al. [41], the treatment group was small and patients were only treated with tiotropium for 12 weeks. In the study by POWRIE et al. [40], the amount of sputum was reduced after tiotropium treatment, which might have resulted in increased cytokine concentrations. Future studies using different methods to assess inflammation could therefore resolve the question of whether anticholinergics indeed have antiinflammatory properties in patients with COPD. At present, there is no evidence for such a role.

In conclusion, the results of our study demonstrate that inhibition of the $\mathrm{M}_{3}$ receptor prevents inflammation in response to cigarette smoke exposure in mice. This confirms the previously established pro-inflammatory role of acetylcholine in the pathophysiology of airway diseases, and demonstrates that this is solely mediated via $\mathrm{M}_{3}$ receptors, since knockout of the $\mathrm{M}_{1}$ and $\mathrm{M}_{2}$ receptor aggravated inflammation compared to wild-type mice. This study therefore opens new perspectives on $M_{3}$ receptor selective anticholinergics to specifically target airway inflammation.

\section{References}

Barnes PJ. Chronic obstructive pulmonary disease. N Engl J Med 2000; 343: 269-280.

Barnes PJ. Immunology of asthma and chronic obstructive pulmonary disease. Nat Rev Immunol 2008; 8: 183-192. Postma DS, Timens W. Remodeling in asthma and chronic obstructive pulmonary disease. Proc Am Thorac Soc 2006; 3: 434-439.

4 Gross NJ, Skorodin MS. Role of the parasympathetic system in airway obstruction due to emphysema. N Engl J Med 1984; 311: 421-425.

5 Lee AM, Jacoby DB, Fryer AD. Selective muscarinic receptor antagonists for airway diseases. Curr Opin Pharmacol 2001; 1: 223-229.

6 Kistemaker LE, Oenema TA, Meurs H, et al. Regulation of airway inflammation and remodeling by muscarinic receptors: perspectives on anticholinergic therapy in asthma and COPD. Life Sci 2012; 91: 1126-1133.

7 Roffel AF, Elzinga CR, Van Amsterdam RG, et al. Muscarinic M2 receptors in bovine tracheal smooth muscle: discrepancies between binding and function. Eur J Pharmacol 1988; 153: 73-82.

8 Gosens R, Zaagsma J, Meurs H, et al. Muscarinic receptor signaling in the pathophysiology of asthma and COPD. Respir Res 2006; 7: 73.

9 Wessler I, Kirkpatrick CJ. Acetylcholine beyond neurons: the non-neuronal cholinergic system in humans. $\mathrm{Br} J$ Pharmacol 2008; 154: 1558-1571. 
10 Kummer W, Lips KS, Pfeil U. The epithelial cholinergic system of the airways. Histochem Cell Biol 2008; 130: 219-234.

11 Gwilt CR, Donnelly LE, Rogers DF. The non-neuronal cholinergic system in the airways: an unappreciated regulatory role in pulmonary inflammation? Pharmacol Ther 2007; 115: 208-222.

12 Gosens R, Rieks D, Meurs H, et al. Muscarinic M3 receptor stimulation increases cigarette smoke-induced IL-8 secretion by human airway smooth muscle cells. Eur Respir J 2009; 34: 1436-1443.

13 Profita M, Bonanno A, Montalbano AM, et al. Cigarette smoke extract activates human bronchial epithelial cells affecting non-neuronal cholinergic system signalling in vitro. Life Sci 2011; 89: 36-43.

14 Profita M, Bonanno A, Siena L, et al. Acetylcholine mediates the release of IL-8 in human bronchial epithelial cells by a NFкB/ERK-dependent mechanism. Eur J Pharmacol 2008; 582: 145-153.

15 Profita M, Giorgi RD, Sala A, et al. Muscarinic receptors, leukotriene B4 production and neutrophilic inflammation in COPD patients. Allergy 2005; 60: 1361-1369.

16 Wollin L, Pieper MP. Tiotropium bromide exerts anti-inflammatory activity in a cigarette smoke mouse model of COPD. Pulm Pharmacol Ther 2010; 23: 345-354.

17 Pera T, Zuidhof A, Valadas J, et al. Tiotropium inhibits pulmonary inflammation and remodelling in a guinea pig model of COPD. Eur Respir J 2011; 28: 789-796.

18 Vacca G, Randerath WJ, Gillissen A. Inhibition of granulocyte migration by tiotropium bromide. Respir Res 2011; 12: 24 .

19 Fisahn A, Yamada M, Duttaroy A, et al. Muscarinic induction of hippocampal gamma oscillations requires coupling of the M1 receptor to two mixed cation currents. Neuron 2002; 33: 615-624.

20 Gomeza J, Shannon H, Kostenis E, et al. Pronounced pharmacologic deficits in M2 muscarinic acetylcholine receptor knockout mice. Proc Natl Acad Sci USA 1999; 96: 1692-1697.

21 Yamada M, Miyakawa T, Duttaroy A, et al. Mice lacking the M3 muscarinic acetylcholine receptor are hypophagic and lean. Nature 2001; 410: 207-212.

22 Bühling F, Lieder N, Kühlmann UC, et al. Tiotropium suppresses acetylcholine-induced release of chemotactic mediators in vitro. Respir Med 2007; 101: 2386-2394.

23 Sato E, Koyama S, Okubo Y, et al. Acetylcholine stimulates alveolar macrophages to release inflammatory cell chemotactic activity. Am J Physiol 1998; 274: L970-L979.

24 Meurs H, Dekkers BG, Maarsingh H, et al. Muscarinic receptors on airway mesenchymal cells: novel findings for an ancient target. Pulm Pharmacol Ther 2013; 26: 145-155.

25 Koyama S, Rennard SI, Robbins RA. Acetylcholine stimulates bronchial epithelial cells to release neutrophil and monocyte chemotactic activity. Am J Physiol 1992; 262: L466-L471.

26 Reinheimer T, Möhlig T, Zimmermann S, et al. Muscarinic control of histamine release from airways. Inhibitory M1-receptors in human bronchi but absence in rat trachea. Am J Respir Crit Care Med 2000; 162: 534-538.

27 Lamb D, Lumsden A. Intra-epithelial mast cells in human airway epithelium: evidence for smoking-induced changes in their frequency. Thorax 1982; 37: 334-342.

28 Jeffery PK. Structural and inflammatory changes in COPD: a comparison with asthma. Thorax 1998; 53: 129-136.

29 Ishihara H, Shimura S, Satoh M, et al. Muscarinic receptor subtypes in feline tracheal submucosal gland secretion. Am J Physiol 1992; 262: L223-L228.

30 Boddeke HW, Buttini M. Pharmacological properties of cloned muscarinic receptors expressed in A9 L cells; comparison with in vitro models. Eur J Pharmacol 1991; 202: 151-157.

31 Schlenz H, Kummer W, Jositsch G, et al. Muscarinic receptor-mediated bronchoconstriction is coupled to caveolae in murine airways. Am J Physiol Lung Cell Mol Physiol 2010; 298: L626-L636.

32 Garssen J, Van Loveren H, Gierveld CM, et al. Functional characterization of muscarinic receptors in murine airways. Br J Pharmacol 1993; 109: 53-60.

33 Casarosa P, Bouyssou T, Germeyer S, et al. Preclinical evaluation of long-acting muscarinic antagonists: comparison of tiotropium and investigational drugs. J Pharmacol Exp Ther 2009; 330: 660-668.

34 Barnes PJ. The pharmacological properties of tiotropium. Chest 2000; 117: Suppl. 2, 63S-66S.

35 Gosens R, Nelemans SA, Grootte Bromhaar MM, et al. Muscarinic M3-receptors mediate cholinergic synergism of mitogenesis in airway smooth muscle. Am J Respir Cell Mol Biol 2003; 28: 257-262.

36 Bos IS, Gosens R, Zuidhof $\mathrm{AB}$, et al. Inhibition of allergen-induced airway remodelling by tiotropium and budesonide: a comparison. Eur Respir J 2007; 30: 653-661.

37 Tashkin DP, Celli B, Senn S, et al. A 4-year trial of tiotropium in chronic obstructive pulmonary disease. $N$ Engl J Med 2008; 359: 1543-1554.

38 Liesker JJ, Bathoorn E, Postma DS, et al. Sputum inflammation predicts exacerbations after cessation of inhaled corticosteroids in COPD. Respir Med 2011; 105: 1853-1860.

39 Bhowmik A, Seemungal TA, Sapsford RJ, et al. Relation of sputum inflammatory markers to symptoms and lung function changes in COPD exacerbations. Thorax 2000; 55: 114-120.

40 Powrie DJ, Wilkinson TM, Donaldson GC, et al. Effect of tiotropium on sputum and serum inflammatory markers and exacerbations in COPD. Eur Respir J 2007; 30: 472-478.

41 Perng DW, Tao CW, Su KC, et al. Anti-inflammatory effects of salmeterol/fluticasone, tiotropium/fluticasone or tiotropium in COPD. Eur Respir J 2009; 33: 778-784. 